\begin{abstract}
Iranica
Abstracta Iranica Revue bibliographique pour le domaine irano-aryen

Volume 34-35-36 | 2017

Comptes rendus des publications de 2011-2013
\end{abstract}

\title{
Michael Roaf. Armenians depicted on Achaemenid monuments
}

Sébastien Gondet

\section{(2) OpenEdition}

1 Journals

\section{Édition électronique}

URL : http://journals.openedition.org/abstractairanica/42103

DOI : 10.4000/abstractairanica.42103

ISSN : 1961-960X

Éditeur :

CNRS (UMR 7528 Mondes iraniens et indiens), Éditions de l'IFRI

Référence électronique

Sébastien Gondet, " Michael Roaf. Armenians depicted on Achaemenid monuments », Abstracta Iranica [En ligne], Volume 34-35-36 | 2017, document 107, mis en ligne le 30 juillet 2017, consulté le 26 septembre 2020. URL : http://journals.openedition.org/abstractairanica/42103 ; DOI : https://doi.org/ 10.4000/abstractairanica.42103

Ce document a été généré automatiquement le 26 septembre 2020.

Tous droits réservés 


\title{
Michael Roaf. Armenians depicted on Achaemenid monuments
}

\author{
Sébastien Gondet
}

\section{RÉFÉRENCE}

Michael Roaf. «Armenians depicted on Achaemenid monuments », in : P. Avetisyan, A. Bobokhyan, eds., Archaeology of Armenia in regional context. Proceedings of the International Conference dedicated to the 50th Anniversary of the Institute of Archaeology and Ethnography. Held on September 15-17, 2009 in Yerevan. Yerevan, 2012, p. 208-218.

1 L'A. est un des spécialistes des bas-reliefs des délégations de l'Apadana de la terrasse de Persépolis auxquels il a consacré de nombreuses études. Cet article s'inscrit dans cette série.

2 Si la province d'Arménie est pour la première fois nommée sur l'inscription de Darius à Behistun, elle a été intégrée à l'empire achéménide dès les campagnes de Cyrus au milieu du VI ${ }^{\mathrm{e}}$ s. av. J.-C. Toutefois sur les différentes représentations des « Arméniens » reproduites sur les monuments royaux d'époque achéménide très peu d'éléments vestimentaires permettent de les distinguer des Mèdes ou des Cappadociens. On aurait donc un costume caractéristique des Iraniens du nord-ouest, donc de l'élite dirigeante, nouvellement arrivés mais non de celui des populations locales qui occupaient l'Arménie dès avant la conquête achéménide. 


\section{AUTEURS}

\section{SÉBASTIEN GONDET}

UMR 5133 CNRS-Université de Lyon 